\title{
Dose-Dependent Solubility-Permeability Interplay for Poorly Soluble Drugs under Non-Sink Conditions
}

\author{
Kazuya Sugita ${ }^{1,2}$, Noriyuki Takata ${ }^{2}$ a and Etsuo Yonemochi ${ }^{1, *(D)}$ \\ 1 Department of Physical Chemistry, Hoshi University, 2-4-41, Ebara, Shinagawa, Tokyo 142-8501, Japan; \\ sugita.kazuya55@chugai-pharm.co.jp \\ 2 Quality Development Department, Chugai Pharma Manufacturing Co., Ltd., 5-5-1, Ukima, Kita, Tokyo \\ 115-8543, Japan; takatanry@chugai-pharm.co.jp \\ * Correspondence: e-yonemochi@hoshi.ac.jp; Tel./Fax: +81-3-5498-5048
}

check for updates

Citation: Sugita, K.; Takata, N.; Yonemochi, E. Dose-Dependent Solubility-Permeability Interplay for Poorly Soluble Drugs under Non-Sink Conditions. Pharmaceutics 2021, 13, 323. https://doi.org/10.3390/ pharmaceutics 13030323

Academic Editor: Im-Sook Song

Received: 1 February 2021

Accepted: 26 February 2021

Published: 2 March 2021

Publisher's Note: MDPI stays neutral with regard to jurisdictional claims in published maps and institutional affiliations.

Copyright: (c) 2021 by the authors. Licensee MDPI, Basel, Switzerland. This article is an open access article distributed under the terms and conditions of the Creative Commons Attribution (CC BY) license (https:/ / creativecommons.org/licenses/by/ $4.0 /)$.

\begin{abstract}
We investigated the solubility-permeability interplay using a solubilizer additive under non-sink conditions. Sodium lauryl sulfate (SLS) was used as a solubilizer additive. The solubility and permeability of two poorly soluble drugs at various doses, with or without SLS, were evaluated by flux measurements. The total permeated amount of griseofulvin, which has high permeability, increased by the addition of SLS. On the other hand, triamcinolone, which has low permeability, showed an almost constant rate of permeation regardless of the SLS addition. The total permeated amount of griseofulvin increased by about $20-30 \%$ when the dose amount exceeded its solubility, whereas its concentration in the donor chamber remained almost constant. However, the total permeated amount of triamcinolone was almost constant regardless of dose amount. These results suggest that the permeability of the unstirred water layer (UWL) may be affected by SLS and solid drugs for high-permeable drugs. The effect of solid drugs could be explained by a reduction in the apparent UWL thickness. For the appropriate evaluation of absorption, it would be essential to consider these effects.
\end{abstract}

Keywords: non-sink condition; solubility-permeability interplay; unstirred water layer; poorly soluble drugs; solubilizer additive

\section{Introduction}

In vitro tools that can assess the absorption performance of solid oral formulations, such as a dissolution test, play an important role in pharmaceutical development [1-8]. These in vitro tools have multiple purposes: selecting the formulation in the pre-clinical stage [2-5], optimizing both the formulation and the manufacturing process in the clinical stage [5], and conducting quality control and bioequivalence studies in the commercial stage [9-14]. Recent studies show that more than 70\% of drug candidates have low solubility, classified in the Biopharmaceutical Classification System (BCS) as BCS class II or IV $[3,4,15]$. Their low solubility can dramatically limit their absorption. To increase the solubility of these drugs, various solubilizer additives, like surfactants and cyclodextrins (CDs), are often added to the formulations [16,17].

The most commonly used in vitro tool, dissolution testing, measures the dissolution rate and solubility of drugs to assess their absorption performance. However, some studies report that the results from the in vitro dissolution testing of formulations that include solubilizers often fail to predict the in vivo absorption [6,18-22]. A major reason for these inconsistent results may be found in the solubility-permeability interplay, wherein solubilizer additives increase drug solubility but decrease permeability. Some papers have reported that even though solubilizer additives successfully increase drug solubility, this interplay hinders in vivo absorption [23-26].

Intestinal membrane transport of drugs in the gastrointestinal tract (GIT) involves two processes: transcellular diffusion and paracellular diffusion $[27,28]$ (pp. 297-307). 
Transcellular diffusion is generally considered to determine drug permeability. Transcellular diffusion can be further divided into two processes: passive diffusion and active transport by carriers/transporters. Both processes affect the permeability of drugs, but the solubility-permeability interplay only occurs during passive diffusion; therefore, this study will focus only on passive diffusion.

Drug molecules dissolved in the GIT after oral administration can take on a variety of new forms; they can be ionized, captured in micelles, or drawn into complexes with other molecules. Among these, the un-ionized free molecules-those not tethered to complexes-are the ones that mainly affect permeability, and they are called un-ionized free drugs (UFDs) [29,30]. Solubilizer additives like surfactants and CDs increase the apparent solubility of drugs by forming micelles and trapping molecules within them or by directly binding to the molecules. However, solubilizers do not change the amount of UFDs, and therefore, the fraction of UFDs in the dissolved molecules decreases, which means the apparent permeability of drugs also decreases because of the solubilizers. The effect of the solubility-permeability interplay on drug absorption is a big issue that has been investigated in both in vitro and in vivo studies. Beig et al. examined the solubilitypermeability interplay of CDs using in vitro studies [31-33]. Miller et al. confirmed a similar interplay effect by sodium lauryl sulfate (SLS) also using in vitro studies [34]. Hens et al. studied the effect of bile micelles on the solubility-permeability interplay by measuring the in vivo absorption of fenofibrate in healthy volunteers [35].

A lot of BCS class II and IV drugs cannot be dissolved completely in the gastrointestinal tract (GIT). When a drug is not completely dissolved, the condition is referred to a non-sink condition. Therefore, to appropriately evaluate drug absorption, we must understand the solubility-permeability relationship under realistic non-sink conditions. Unfortunately, most studies on the solubility-permeability interplay involve sink conditions in which drugs are dissolved completely. Under sink conditions, the effect of the solubility-permeability interplay on drug absorption can be explained by a mechanism involving two continuous processes in passive diffusion; the first is the diffusion of drug molecules in the unstirred water layer (UWL) on the membrane surface, and the second is diffusion in the membrane itself. As the membrane is composed of phospholipids, drug molecules should be in lipophilic form to be partitioned to the membrane. Because a UFD is far more lipophilic in the GIT than in any other form, it is thought that a UFD alone can permeate during passive diffusion. This theory has been confirmed by numerous studies over the years [30]. Therefore, it is assumed that the UFD amount alone determines permeability in the membrane. However, in the UWL, drug molecule diffusion could be affected by other forms, in addition to the UFD [36]. UWL diffusion may depend on the unique properties of drug molecules and solubilizer additives. Some studies have successfully confirmed the solubility-permeability interplay by solubilizer additives under sink conditions using the absorption mechanism described above [31-34]. However, it has also been reported that undissolved solid drugs could affect the diffusion of drug molecules in the UWL under non-sink conditions [37-39]. These studies suggest that the permeation of some drugs under non-sink conditions might be faster than that under sink conditions. Unfortunately, there have been too few studies on the solubility-permeability interplay under non-sink conditions.

The purpose of this study is to investigate the relationship between drug solubility, the amount of UFDs, and permeability under non-sink conditions. We used SLS, which is often used as a solubilizer additive in the formulations, and we used griseofulvin and triamcinolone, which have very different solubilities and lipophilicities, as model compounds (Figure 1 and Table 1). We measured the solubility and permeability of these compounds with or without SLS. To investigate the difference between sink and non-sink conditions, the sample dose was changed for each measurement. 


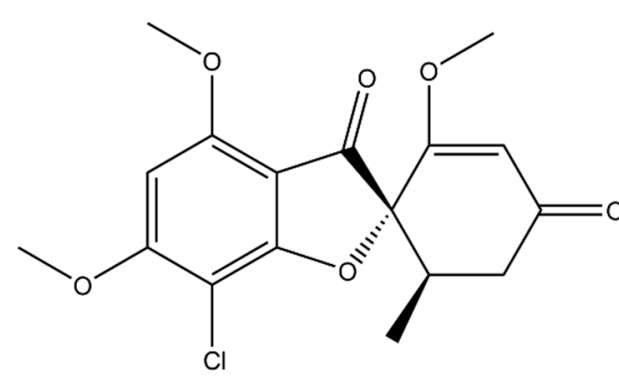

(a) griseofulvin

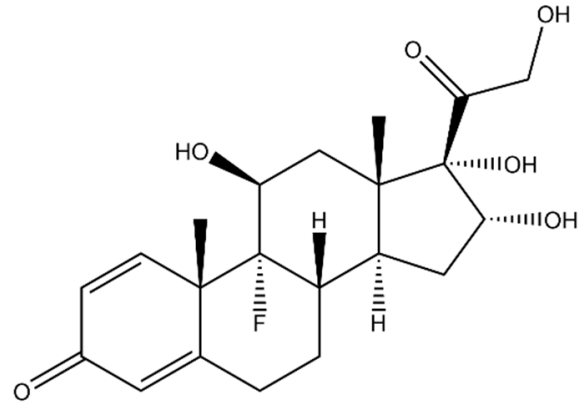

(b) triamcinolone

Figure 1. The molecular structure of griseofulvin (a) and triamcinolone (b).

Table 1. Physicochemical properties of griseofulvin and triamcinolone.

\begin{tabular}{ccc}
\hline Physicochemical Properties & Griseofulvin & Triamcinolone \\
\hline Molecular weight $(\mathrm{MW})$ & 352.77 & 394.43 \\
Ionization properties & Neutral & Neutral \\
$\log \mathrm{P}^{1}$ & $2.18[40,41]$ & $1.03[40,42]$ \\
Aqueous solubility $(\mu \mathrm{g} / \mathrm{mL})^{2}$ & $29.9[40,41]$ & $158[40,42]$ \\
\hline
\end{tabular}

${ }^{1}$ The partition coefficient is for partitioning between octanol and water. ${ }^{2}$ Aqueous solubility was measured at $37^{\circ} \mathrm{C}$.

This study can clarify the effect of solubilizer additives and sample dosage on drug permeability and absorption under non-sink conditions.

\section{Theoretical Basis}

In discussing how the solubility-permeability interplay is mediated by solubilizer additives, such as surfactants, we assume that the drug permeability is determined by passive diffusion and that drug molecules are not ionized in the solvent. When solubilizer additives increase apparent solubility, the theoretical relationship between solubility and permeability is described as follows.

Based on Fick's first law, flux in the drug permeation can be expressed as shown in Equation (1): [36,43]

$$
\mathrm{J}(\mathrm{t})=\mathrm{P}_{\mathrm{app}} \mathrm{C}_{\mathrm{app}}(\mathrm{t})
$$

where $P_{\text {app }}$ is the effective or apparent permeability and $C_{a p p}(t)$ is the apparent drug concentration.

As described in the introduction, overall permeation can be divided into membrane permeation and UWL permeation. Thus, the apparent permeability $\left(\mathrm{P}_{\mathrm{app}}\right)$ is calculated using both apparent membrane permeability $\left(\mathrm{P}_{\mathrm{m}(\mathrm{app})}\right)$ and apparent UWL permeability $\left(\mathrm{P}_{\mathrm{UWL}}(\mathrm{app})\right)$, as shown in Equation (2) $[43,44]$ :

$$
\frac{1}{\mathrm{P}_{\mathrm{app}}}=\frac{1}{\mathrm{P}_{\mathrm{m}(\mathrm{app})}}+\frac{1}{\mathrm{P}_{\mathrm{UWL}(\mathrm{app})}}
$$

$\mathrm{P}_{\mathrm{m}(\mathrm{app})}$ is calculated using the fraction of UFDs $\left(\mathrm{F}_{\mathrm{U}}\right)$ as shown in Equation (3) [45]:

$$
\mathrm{P}_{\mathrm{m}(\mathrm{app})}=\mathrm{F}_{\mathrm{U}} \mathrm{P}_{\mathrm{m}(\mathrm{U})}
$$

where $\mathrm{P}_{\mathrm{m}(\mathrm{U})}$ is the intrinsic permeability of UFDs. $\mathrm{F}_{\mathrm{U}}$ is calculated by the solubility of drugs as shown in Equation (4):

$$
\mathrm{F}_{\mathrm{U}}=\frac{\mathrm{S}_{\mathrm{U}}}{\mathrm{S}}
$$

where $S_{U}$ is the intrinsic solubility of drugs in the absence of solubilizer additives and $\mathrm{S}$ is the apparent solubility of drugs. 
$\mathrm{P}_{\mathrm{UWL}}$ (app) can be expressed using the apparent aqueous diffusivity ( $\mathrm{D}_{\mathrm{aq}}(\mathrm{app})$ ) from Fick's first law as shown in Equation (5):

$$
\mathrm{P}_{\mathrm{UWL}(\mathrm{app})}=\frac{\mathrm{D}_{\mathrm{aq}(\mathrm{app})}}{\mathrm{h}_{\mathrm{UWL}(\mathrm{app})}}
$$

where $\mathrm{h}_{\mathrm{UWL} \text { (app) }}$ is the apparent thickness of the UWL. When there are no solubilizer additives in the drug formulation or test media in the permeability measurements, Equation (5) can be described as shown in Equation (6):

$$
\mathrm{P}_{\mathrm{UWL}(\mathrm{U})}=\frac{\mathrm{D}_{\mathrm{aq}(\mathrm{U})}}{\mathrm{h}_{\mathrm{UWL}(\mathrm{U})}}
$$

where $h_{U W L}(\mathrm{U})$ is the intrinsic thickness of the $U W L$ and $D_{a q}(\mathrm{U})$ is the intrinsic aqueous diffusivity of UFDs. The thickness of the UWL can be determined based on rotation speed in the flux experiment $[46,47]$. If the rotation speed is constant, we can assume that the thickness of the UWL is constant, independent of the addition of solubilizer additives, as shown in Equation (7):

$$
\mathrm{h}_{\mathrm{UWL}(\mathrm{app})}=\mathrm{h}_{\mathrm{UWL}(\mathrm{U})}
$$

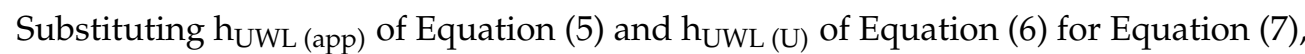
$\mathrm{P}_{\mathrm{UWL}(\mathrm{app})}$ is described as shown in Equation (8):

$$
\mathrm{P}_{\mathrm{UWL}(\mathrm{app})}=\mathrm{P}_{\mathrm{UWL}(\mathrm{U})} \times \frac{\mathrm{D}_{\mathrm{aq}(\mathrm{app})}}{\mathrm{D}_{\mathrm{aq}(\mathrm{U})}}
$$

The apparent aqueous diffusivity $\left(\mathrm{D}_{\mathrm{aq}(\mathrm{app})}\right)$ is a combined total of each fraction of aqueous diffusivity as shown in Equation (9) [36]:

$$
\mathrm{D}_{\mathrm{aq}(\mathrm{app})}=\mathrm{F}_{\mathrm{U}} \mathrm{D}_{\mathrm{aq}(\mathrm{U})}+\left(1-\mathrm{F}_{\mathrm{U}}\right) \mathrm{D}_{\mathrm{aq}(\mathrm{B})}
$$

where $F_{U}$ is the same fraction of UFDs as in Equation (4) and $D_{a q}(B)$ is the aqueous diffusivity of drug molecules bound to solubilizer additives. $P_{\mathrm{UWL}}$ (app) can be calculated by Equations (6), (8), and (9) as shown in Equation (10):

$$
\mathrm{P}_{\mathrm{UWL}(\text { app })}=\frac{1}{\mathrm{~h}_{\mathrm{UWL}(\mathrm{app})}}\left\{\mathrm{F}_{\mathrm{U}} \mathrm{D}_{\mathrm{aq}(\mathrm{U})}+\left(1-\mathrm{F}_{\mathrm{U}}\right) \mathrm{D}_{\mathrm{aq}(\mathrm{B})}\right\}
$$

If we know the aqueous diffusivity of each component and the thickness of the UWL, the apparent permeability $\mathrm{P}_{\text {app }}$ can be calculated based on the drug solubility using Equations (2), (3), and (10).

\section{Materials and Methods}

\subsection{Materials}

Griseofulvin and triamcinolone were purchased from Tokyo Chemical Industry Co., Ltd. (Tokyo, Japan). Buffer components (sodium dihydrogen phosphate $\left(\mathrm{NaH}_{2} \mathrm{PO}_{4}\right)$, sodium hydroxide $(\mathrm{NaOH})$, sodium chloride $(\mathrm{NaCl}))$, acetonitrile $(\mathrm{MeCN})$, trifluoroacetic acid (TFA), ethylene glycol, N,N-dimethylacetamide (DMA), and dimethyl sulfoxide (DMSO) were purchased from FUJI FILM Wako Pure Chemical Co. (Osaka, Japan). MeCN and TFA were HPLC grade. Ethylene glycol and DMA were Wako special grade. DMSO was a guaranteed reagent. The gastrointestinal tract (GIT) lipid and the acceptor sink buffer (ASB) were purchased from Pion Inc. (Billerica, MA, USA). 


\subsection{Methods}

\subsubsection{Flux Measurements}

The flux was measured by MicroFlux ${ }^{\mathrm{TM}}$ (Pion Inc., Billerica, MA, USA). Two chambers in this device were separated by a polyvinylidene fluoride (PVDF) membrane filter of $0.45 \mu \mathrm{m}$ pore size with $25 \mu \mathrm{L}$ of GIT lipid solution (Pion Inc., Billerica, MA, USA). Next, $20 \mathrm{~mL}$ of ASB (Pion Inc., Billerica, MA, USA) was added into each acceptor chamber, and $20 \mathrm{~mL}$ of the test sample solution was added to each donor chamber. Details of the test sample solution in the donor chambers are summarized in Table 2. The sample dose amount was set based on the preliminary solubility study. Then, $5 \mu \mathrm{g} / \mathrm{mL}$ of griseofulvin and $100 \mu \mathrm{g} / \mathrm{mL}$ of triamcinolone were evaluated under sink conditions, and other samples were evaluated under non-sink conditions. The SLS concentration was set based on the reported SLS amount used in the drug formulation and the reported solvent volume in human GIT. Japan's Ministry of Health, Labor and Welfare reported that the maximum SLS amount administered was $300 \mathrm{mg}$ [48]. The solvent volume of the small intestine in a fasted condition, where most of orally administered drug is absorbed, was reported to be around $50-300 \mathrm{~mL}[49,50]$. Therefore, the maximum SLS concentration in the human small intestine could be around $0.10-0.60 \%(w / w)$. If enough SLS was used in the drug formulation as solubilizer additive, more than $0.05 \%(w / w)$ SLS could be included in the solvent of the small intestine. To prepare $5 \mu \mathrm{g} / \mathrm{mL}$ of griseofulvin and $100 \mu \mathrm{g} / \mathrm{mL}$ of triamcinolone, $19.9 \mathrm{~mL}$ of test media and $0.1 \mathrm{~mL}$ of the concentrated sample solution prepared by DMSO were mixed. To prepare other test sample solutions, the determined test sample amount was added to a test tube containing test media. These samples were placed on the rotation stirrers in a water bath at $37^{\circ} \mathrm{C}$ and stirred well. After stirring, these samples were suspended visually. The measurements were started by adding $20 \mathrm{~mL}$ of these test sample solutions to the donor chambers. Cross-bar magnetic stirrers were located in each chamber, rotating at $150 \mathrm{rpm}$. The media in the donor and the acceptor chambers were maintained at $37^{\circ} \mathrm{C}$ during measurement. All flux measurements were performed in triplicate.

Table 2. List of test sample solution conditions in the donor chambers.

\begin{tabular}{|c|c|c|}
\hline Compound & Test Media & $\begin{array}{c}\text { Sample Dose Amount } \\
(\mu \mathrm{g} / \mathrm{mL})\end{array}$ \\
\hline Griseofulvin & $\begin{array}{c}\text { pH } 6.5 \text { phosphate buffer (pH } 6.5 \text { buffer) } \\
\text { pH } 6.5 \text { phosphate buffer with } 0.05 \%(w / w) \\
\text { sodium lauryl sulfate (SLS) (pH } 6.5 \text { buffer + } \\
0.05 \% \text { SLS) }\end{array}$ & $\begin{array}{l}5,50,200, \text { and } 1000 \\
5,50,200, \text { and } 1000\end{array}$ \\
\hline Triamcinolone & $\begin{array}{c}\text { pH } 6.5 \text { buffer } \\
\text { pH } 6.5 \text { buffer }+0.05 \% \text { SLS }\end{array}$ & $\begin{array}{l}100,500,2000 \text {, and } 10,000 \\
100,500,2000 \text {, and } 10,000\end{array}$ \\
\hline
\end{tabular}

The concentration-time profiles were determined via manual sampling from the donor chambers and acceptor chambers during flux measurements. At 0, 30, 60, 120, 240, and $360 \mathrm{~min}, 100 \mu \mathrm{L}$ of the acceptor chamber solution was withdrawn and diluted to $100 \mu \mathrm{L}$ ( $2 \times$ dilution) of 3:2 DMA:ethylene glycol $(v / v)$. At the same time point, $400 \mu \mathrm{L}$ of the donor chamber solution was withdrawn and filtered through a polytetrafluoroethylene (PTFE) membrane filter of $0.22 \mu \mathrm{m}$ pose size. Then, $100 \mu \mathrm{L}$ of the filtered solution was diluted to $100 \mu \mathrm{L}$ ( $2 \times$ dilution) of 3:2 DMA:ethylene glycol $(v / v)$. The sample concentration was determined by ultra-high-performance liquid chromatography (UHPLC).

The solubility of each model compound at $37^{\circ} \mathrm{C}$ for each test medium was determined by using the donor chamber sample concentration at $0 \mathrm{~min}$ of $1000 \mu \mathrm{g} / \mathrm{mL}$ dose for griseofulvin and $10,000 \mu \mathrm{g} / \mathrm{mL}$ dose for triamcinolone.

From the obtained concentration-time profiles in the acceptor chambers, the flux (J) was calculated. The flux refers to the mass transfer through the membrane, and it is defined 
as the total amount of material crossing one unit area of the membrane per unit time, as described by Equation (11):

$$
J(t)=\frac{1}{A} \cdot \frac{d m}{d t}=\frac{V}{A} \cdot \frac{d C(t)}{d t}
$$

where $\mathrm{dm} / \mathrm{dt}(\mu \mathrm{g} / \mathrm{mL})$ is the total amount of material crossing the membrane per unit time, $A$ is the area of the membrane $\left(1.54 \mathrm{~cm}^{2}\right), \mathrm{V}$ is the volume of the acceptor chamber $(20 \mathrm{~mL})$, and $\mathrm{dC}(\mathrm{t}) / \mathrm{dt}(\mu \mathrm{g} /(\mathrm{mL} \cdot \mathrm{min}))$ is the slope of the concentration-time profiles in the acceptor chambers. Time intervals were selected in each test to exclude the lag time of the concentration-time profile and calculate the initial flux. The selected time intervals are described in the Results section. Based on Fick's first law, assuming the sink condition in the acceptor chambers, the flux can be described by Equation (12):

$$
\mathrm{J}(\mathrm{t})=\mathrm{P}_{\mathrm{app}} \mathrm{C}_{\mathrm{D}}(\mathrm{t})
$$

where $P_{\text {app }}$ is the apparent permeability of drugs and $C_{D}(t)$ is the drug concentration in the donor chambers. As the initial flux was calculated in this study, $C_{D}(t)$ at 0 min $\left(=C_{D}\right.$ (0)) was used to calculate $\mathrm{P}_{\mathrm{app}}$ by Equation (12).

\subsubsection{Sample Concentration Measurements by UHPLC}

The sample concentrations were measured on a Waters (Milford, MA) Acquity UPLC H-Class system. An Acquity UPLC ${ }^{\circledR}$ BEH Shield RP18 $1.7 \mu \mathrm{m}, 2.1 \times 50 \mathrm{~mm}$, was used for chromatographic separation. A gradient mobile phase, spanning 95:5 to 0:100 (v/v) water:MeCN (both containing 0.05\%TFA) over $2.0 \mathrm{~min}$, was pumped at a flow rate of $1.0 \mathrm{~mL} / \mathrm{min}$. The injection volume and ultraviolet (UV) wavelength for griseofulvin were $5 \mu \mathrm{L}$ and $240 \mathrm{~nm}$, respectively. The injection volume and ultraviolet (UV) wavelength for triamcinolone were $1 \mu \mathrm{L}$ and $292 \mathrm{~nm}$, respectively.

\section{Results}

\subsection{Effect of SLS on Griseofulvin Solubility and Triamcinolone Solubility}

The solubility of griseofulvin and triamcinolone in each test medium at $37{ }^{\circ} \mathrm{C}$ is shown in Table 3. The solubility of griseofulvin increased by about 2.5 -fold by the addition of $0.05 \%$ SLS. In contrast, the solubility of triamcinolone was mostly constant, independent of the addition of SLS. Compared with triamcinolone, griseofulvin is a lipophilic compound and is easy to solubilize using SLS.

Table 3. Solubility and un-ionized free drug (UFD) amount of griseofulvin and triamcinolone at

\begin{tabular}{|c|c|c|c|c|}
\hline Compound & Test Media & $\begin{array}{l}\text { Solubility } \\
(\mu \mathrm{g} / \mathrm{mL})^{1}\end{array}$ & $\begin{array}{l}\text { UFD Amount } \\
(\mu \mathrm{g} / \mathrm{mL})\end{array}$ & $\begin{array}{c}\text { Fraction of UFD } \\
\left(\mathrm{F}_{\mathrm{U}}\right)\end{array}$ \\
\hline \multirow{2}{*}{ Griseofulvin } & pH 6.5 buffer & $10.75 \pm 0.38$ & 10.75 & 1.00 \\
\hline & $\mathrm{pH} 6.5$ buffer $+0.05 \%$ SLS & $27.40 \pm 0.07$ & 10.75 & 0.39 \\
\hline \multirow[t]{2}{*}{ Triamcinolone } & pH 6.5 buffer & $205.04 \pm 10.34$ & 205.04 & 1.00 \\
\hline & $\mathrm{pH} 6.5$ buffer $+0.05 \%$ SLS & $210.07 \pm 6.54$ & 205.04 & 0.98 \\
\hline
\end{tabular}
$37^{\circ} \mathrm{C}$ in each test medium.

${ }^{1}$ Results represent average solubility \pm Standard deviation (SD) $(n=3)$. UFD, un-ionized free drug.

As both griseofulvin and triamcinolone are neutral compounds, we can assume that these drug molecules are not ionized in the aqueous test media. We can assume that these compounds formed only UFDs in $\mathrm{pH} 6.5$ buffer and that UFDs and the drug molecules bound to SLS in pH 6.5 buffer $+0.05 \%$ SLS. Under non-sink conditions, the amount of UFDs would be constant regardless of the SLS amount. Therefore, the amount and fraction of UFDs were estimated by Equation (4) using the average solubility (Table 3). 


\subsection{Effect of Dose Amount and SLS on Flux and Permeability}

\subsubsection{Griseofulvin}

The concentration-time profiles of griseofulvin in the acceptor chamber as determined by the flux measurements are shown in Figure 2. Those in the donor chamber as determined by the flux measurements are shown in Figure A1. The flux calculated using Equation (11) is shown in Figure 3.

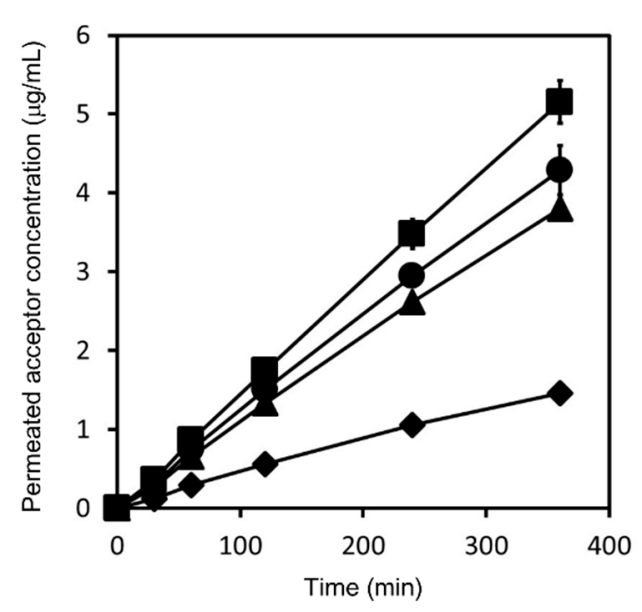

(a) $\mathrm{pH} 6.5$ buffer

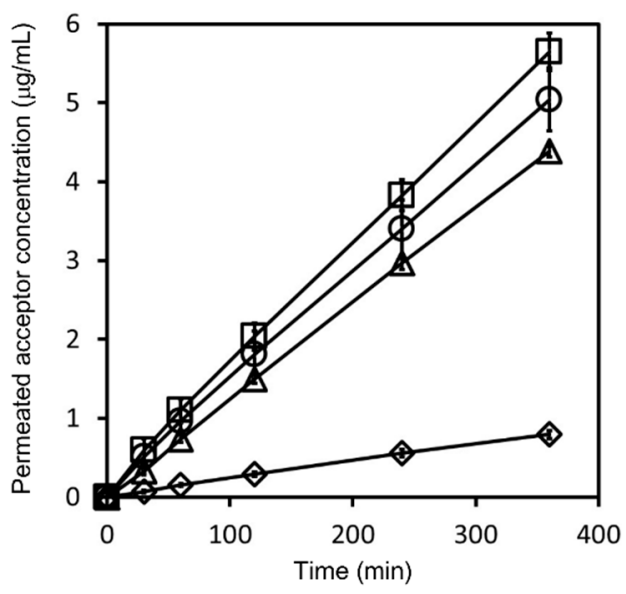

(b) $\mathrm{pH} 6.5$ buffer $+0.05 \%$ SLS

Figure 2. Griseofulvin concentration-time profile in the acceptor chamber as determined by flux measurements. Measurements in $\mathrm{pH} 6.5$ buffer are represented by closed symbols for the $5 \mu \mathrm{g} / \mathrm{mL}$ sample dose $(\diamond), 50 \mu \mathrm{g} / \mathrm{mL}$ sample dose $(\boldsymbol{\Delta}), 200 \mu \mathrm{g} / \mathrm{mL}$ sample dose $(\bullet)$, and $1000 \mu \mathrm{g} / \mathrm{mL}$ sample dose ( $\mathbf{\square})$ (a). Measurements in pH 6.5 buffer $+0.05 \%$ Sodium lauryl sulfate (SLS) are represented by open symbols for the $5 \mu \mathrm{g} / \mathrm{mL}$ sample dose $(\diamond), 50 \mu \mathrm{g} / \mathrm{mL}$ sample dose $(\triangle), 200 \mu \mathrm{g} / \mathrm{mL}$ sample dose $(\bigcirc)$, and $1000 \mu \mathrm{g} / \mathrm{mL}$ sample dose $(\square)(\mathbf{b})$. Results represent the average permeated griseofulvin concentration $\pm \mathrm{SD}(n=3)$.

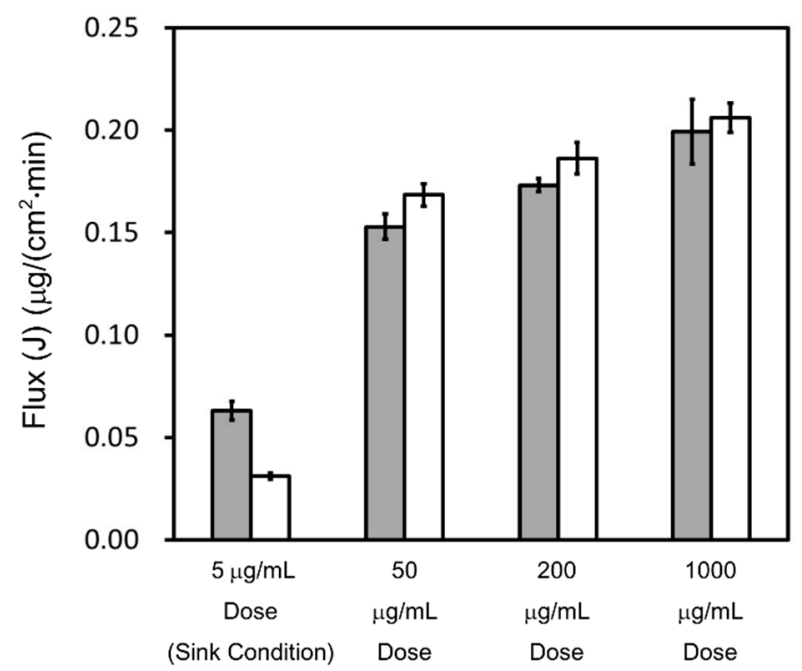

Figure 3. Calculated flux of griseofulvin. A time interval of 30-120 min was selected. The flux in $\mathrm{pH}$ 6.5 buffer is represented by gray bars. The flux in $\mathrm{pH} 6.5$ buffer $+0.05 \%$ SLS is represented by white bars. Results represent the average griseofulvin flux $\pm \mathrm{SD}(n=3)$.

Based on the solubility in Table 3, as for both $\mathrm{pH} 6.5$ buffer and $\mathrm{pH} 6.5$ buffer + $0.05 \%$ SLS, the $5 \mu \mathrm{g} / \mathrm{mL}$ dose samples in the donor chamber were under sink conditions and the 50, 200, and $1000 \mu \mathrm{g} / \mathrm{mL}$ dose samples were under non-sink conditions. The 
sample concentration in the donor chambers for the $5 \mu \mathrm{g} / \mathrm{mL}$ dose correlated well with the prepared sample concentration, and the test samples were visually confirmed to be a transparent solution. On the other hand, the sample concentrations in the donor chamber for the 50,200 , and $1000 \mu \mathrm{g} / \mathrm{mL}$ doses was about $10 \mu \mathrm{g} / \mathrm{mL}$ in $\mathrm{pH} 6.5$ buffer and about $25 \mu \mathrm{g} / \mathrm{mL}$ in $\mathrm{pH} 6.5$ buffer $+0.05 \%$ SLS, which were lower than the prepared sample concentrations. These samples were visually confirmed to be suspensions.

The fluxes under sink conditions were smaller than those under non-sink conditions in both $\mathrm{pH} 6.5$ buffer and $\mathrm{pH} 6.5$ buffer $+0.05 \%$ SLS; this is because the sample concentrations in the donor chambers under sink conditions were lower than those under non-sink conditions. Under sink conditions, at the $5 \mu \mathrm{g} / \mathrm{mL}$ dose, the flux in $\mathrm{pH} 6.5 \mathrm{buffer}+0.05 \%$ SLS was almost half that in $\mathrm{pH} 6.5$ buffer, even though the sample concentration at $0 \mathrm{~min}$ in the donor chamber showed almost the same value. Under non-sink conditions, at the 50,200 , and $1000 \mu \mathrm{g} / \mathrm{mL}$ doses, the flux in $\mathrm{pH} 6.5$ buffer $+0.05 \%$ SLS was slightly higher than that in pH 6.5 buffer. Based on Equation (12), these results suggest that the apparent permeability in $\mathrm{pH} 6.5$ buffer $+0.05 \%$ SLS was almost half that in $\mathrm{pH} 6.5$ buffer.

In addition, in both $\mathrm{pH} 6.5$ buffer and $\mathrm{pH} 6.5$ buffer $+0.05 \%$ SLS, the flux increased by about $10-30 \%$, depending on the dose amount under non-sink conditions, even though the sample concentration at $0 \mathrm{~min}$ in the donor chamber showed almost the same value.

\subsubsection{Triamcinolone}

The concentration-time profiles of triamcinolone in the acceptor chamber, as determined by the flux measurements, are shown in Figure 4, while those in the donor chamber, as determined by the flux measurements, are shown in Figure A2. The flux calculated using Equation (11) is shown in Figure 5.

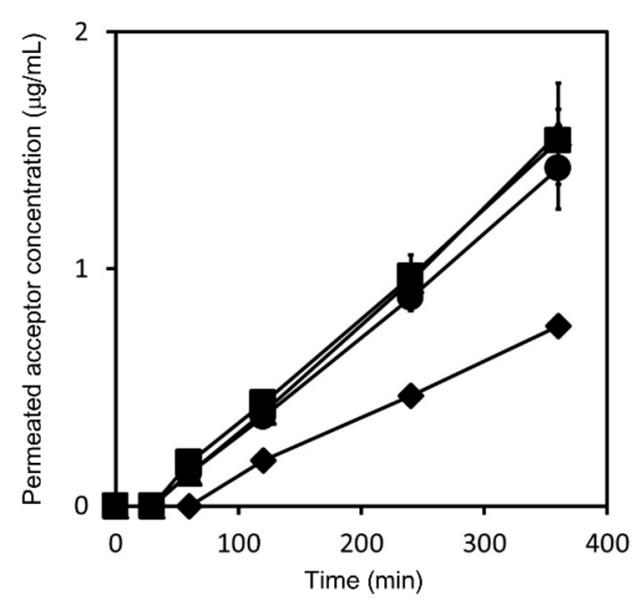

(a) $\mathrm{pH} 6.5$ buffer

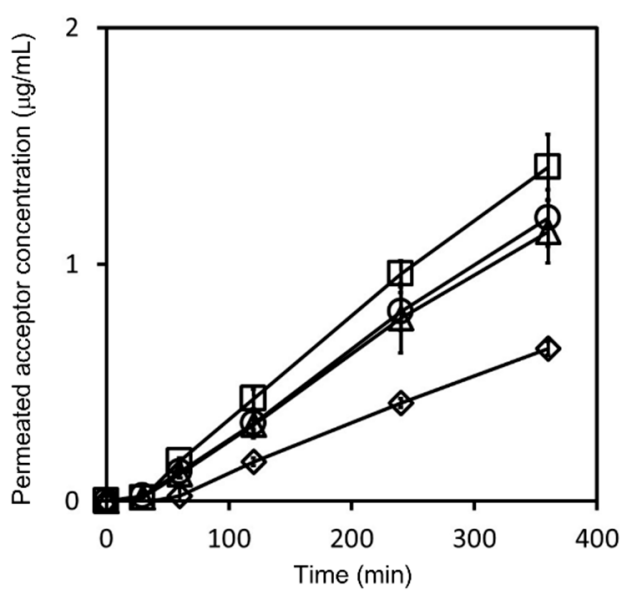

(b) $\mathrm{pH} 6.5$ buffer $+0.05 \%$ SLS

Figure 4. Triamcinolone concentration-time profile in the acceptor chamber, as determined by flux measurements. Measurements in pH 6.5 buffer are represented by closed symbols for the $100 \mu \mathrm{g} / \mathrm{mL}$ sample dose $(\boldsymbol{\bullet}), 500 \mu \mathrm{g} / \mathrm{mL}$ sample dose $(\boldsymbol{\Delta}), 2000 \mu \mathrm{g} / \mathrm{mL}$ sample dose $(\bullet)$, and 10,000 $\mu \mathrm{g} / \mathrm{mL}$ sample dose ( $\mathbf{( a )}$ ). Measurements in $\mathrm{pH} 6.5$ buffer $+0.05 \%$ SLS are represented by open symbols for the $100 \mu \mathrm{g} / \mathrm{mL}$ sample dose $(\diamond), 500 \mu \mathrm{g} / \mathrm{mL}$ sample dose $(\triangle), 2000 \mu \mathrm{g} / \mathrm{mL}$ sample dose $(\bigcirc)$, and $10,000 \mu \mathrm{g} / \mathrm{mL}$ sample dose $(\square)(\mathbf{b})$. Results represent the average permeated triamcinolone concentration $\pm \mathrm{SD}(n=3)$. 


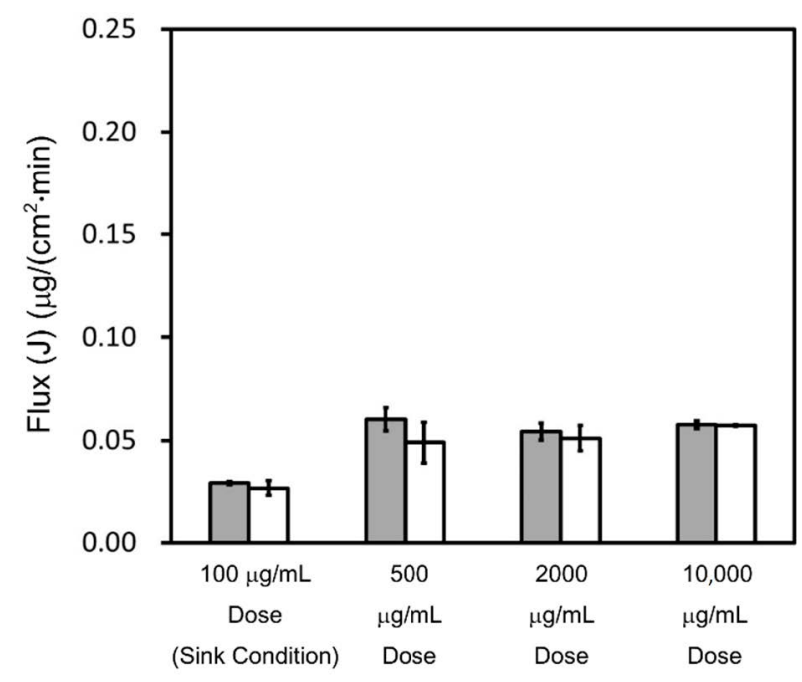

Figure 5. Calculated flux of triamcinolone. A time interval of 120-240 min was selected. The flux in $\mathrm{pH} 6.5$ buffer is represented by gray bars. The flux in $\mathrm{pH} 6.5$ buffer $+0.05 \%$ SLS is represented by white bars. Results represent the average triamcinolone flux $\pm \mathrm{SD}(n=3)$.

Based on the solubility in Table 3, for both $\mathrm{pH} 6.5$ buffer and $\mathrm{pH} 6.5$ buffer $+0.05 \%$ SLS, the $100 \mu \mathrm{g} / \mathrm{mL}$ dose test samples in the donor chamber were under sink conditions and the 500, 2000, and 10,000 $\mu \mathrm{g} / \mathrm{mL}$ dose test samples in the donor chamber were under nonsink conditions. The sample concentration in the donor chamber for the $100 \mu \mathrm{g} / \mathrm{mL}$ dose correlated well with the prepared sample concentration, and the test samples were visually confirmed to be a transparent solution. On the other hand, the sample concentrations in the donor chamber for 500, 2000, and $10,000 \mu \mathrm{g} / \mathrm{mL}$ doses showed about $200 \mu \mathrm{g} / \mathrm{mL}$ in $\mathrm{pH} 6.5$ buffer and $\mathrm{pH} 6.5$ buffer $+0.05 \%$ SLS, which were lower than the prepared sample concentrations. These samples were visually confirmed to be suspensions.

The fluxes under sink conditions were smaller than those under non-sink conditions in both $\mathrm{pH} 6.5$ buffer and $\mathrm{pH} 6.5$ buffer $+0.05 \%$ SLS; this is because the sample concentrations in the donor chambers under sink conditions were lower than those under non-sink conditions. Under sink conditions, at the $100 \mu \mathrm{g} / \mathrm{mL}$ dose, the flux in $\mathrm{pH} 6.5$ buffer $+0.05 \%$ SLS and $\mathrm{pH} 6.5$ buffer showed almost similar values. Under non-sink conditions, in $\mathrm{pH}$ 6.5 buffer, the flux at all doses was also similar. In $\mathrm{pH} 6.5$ buffer $+0.05 \%$ SLS, the flux at 500 and $2000 \mu \mathrm{g} / \mathrm{mL}$ doses was similar. At the $10,000 \mu \mathrm{g} / \mathrm{mL}$ dose, the flux and the donor concentration were about $10 \%$ higher than those at the 500 and $2000 \mu \mathrm{g} / \mathrm{mL}$ doses. Based on Equation (12), unlike griseofulvin, in both $\mathrm{pH} 6.5$ buffer and $\mathrm{pH} 6.5$ buffer $+0.05 \%$ SLS, the apparent permeability was mostly constant and not dependent on the sample dose amount under non-sink conditions.

\subsection{Theoretical Calculation about Permeability}

In this section, we calculated the permeabilities of compounds theoretically using the results and the physicochemical properties of compounds, also applying the equations in the Theoretical Basis section.

In pH 6.5 buffer under sink conditions, because both griseofulvin and triamcinolone are neutral compounds, all the drug molecules in the donor chamber would be UFDs. The intrinsic permeability of UFDs $\left(\mathrm{P}_{\mathrm{app}(\mathrm{U})}\right)$ was calculated by Equation (12) using the drug concentration in the donor chamber and the measured flux (measured $\mathrm{P}_{\mathrm{app}}(\mathrm{U})$ in Table 4). It is reported that the intrinsic aqueous diffusivity of UFDs $\left(D_{a q}(U)\right.$ depends on the molecular weight (MW) and can be empirically estimated by Equation (13) [51] (p. 381):

$$
\log \mathrm{D}_{\mathrm{aq}(\mathrm{U})}=-4.131-0.4531 \log \mathrm{MW}
$$


Table 4. Measured and calculated permeability in $\mathrm{pH} 6.5$ buffer.

\begin{tabular}{ccc}
\hline Compound & Griseofulvin & Triamcinolone \\
\hline MW & 352.77 & 394.43 \\
Measured $\mathrm{P}_{\mathrm{app}(\mathrm{U})}(\mathrm{cm} / \mathrm{min})^{1}$ & $0.0148 \pm 0.0007$ & $0.000304 \pm 0.000010$ \\
\hline Calculated $\mathrm{D}_{\mathrm{aq}}(\mathrm{U})\left(\mathrm{cm}^{2} / \mathrm{s}\right)$ & $5.18 \times 10^{-6}$ & $4.93 \times 10^{-6}$ \\
Calculated $\mathrm{P}_{\mathrm{UWL}(\mathrm{U})}(\mathrm{cm} / \mathrm{min})$ & 0.0311 & 0.0296 \\
Calculated $\mathrm{P}_{\mathrm{m}(\mathrm{U})}(\mathrm{cm} / \mathrm{min})$ & 0.0284 & 0.000307 \\
Calculated $\mathrm{P}_{\mathrm{app}(\mathrm{U})}(\mathrm{cm} / \mathrm{min})$ & 0.0148 & 0.000304 \\
\hline
\end{tabular}

${ }^{1}$ Results represent the average $\mathrm{P}_{\text {app }(\mathrm{U})} \pm \mathrm{SD}(n=3)$. MW, molecular weight. UWL, unstirred water layer.

Using the MW of the model compounds, each $\mathrm{D}_{\mathrm{aq}}(\mathrm{U})$ was calculated (calculated $\mathrm{D}_{\mathrm{aq}}(\mathrm{U})$ in Table 4). The UWL thickness ( $\mathrm{h}_{\mathrm{UWL} \text { (app) }}$ or $\mathrm{h}_{\mathrm{UWL}(\mathrm{U})}$ ) for the MicroFlux ${ }^{\mathrm{TM}}$ measurements in this study was estimated to be around $100 \mu \mathrm{m}$ based on previous studies $[43,44,51]$. The intrinsic UWL permeability of UFDs ( $\mathrm{P}_{\mathrm{UWL}}(\mathrm{U})$ ) was then calculated by Equation (6) (calculated $\mathrm{P}_{\mathrm{UWL}(\mathrm{U})}$ in Table 4). Substituting $\mathrm{P}_{\mathrm{app}(\mathrm{U})}$ and $\mathrm{P}_{\mathrm{UWL}(\mathrm{U})}$ in Equation (2), the intrinsic membrane permeability of UFD $\left(\mathrm{P}_{\mathrm{m}(\mathrm{U})}\right)$ was calculated (calculated $\mathrm{P}_{\mathrm{m}(\mathrm{U})}$ in Table 4). The results suggested that the permeability of griseofulvin is affected by not only

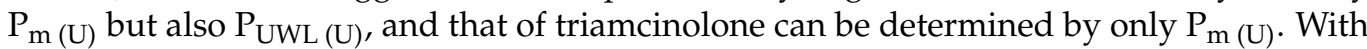
triamcinolone, $\mathrm{P}_{\mathrm{UWL}}(\mathrm{U})$ is much smaller than $\mathrm{P}_{\mathrm{m}(\mathrm{U})}$.

For both model compounds, in $\mathrm{pH} 6.5$ buffer $+0.05 \%$ SLS under sink conditions, the drug molecules in the donor chamber were UFDs and bound to SLS. The apparent permeability $\left(\mathrm{P}_{\mathrm{app}}\right)$ was calculated by Equation (12) using the drug concentration in the donor chamber and the measured flux (measured $P_{a p p}$ in Table 5). The apparent membrane permeability $\left(\mathrm{P}_{\mathrm{m} \text { (app) }}\right)$ was calculated by Equation (3) using the fraction of UFDs $\left(\mathrm{F}_{\mathrm{U}}\right)$ in Table 3 and $\mathrm{P}_{\mathrm{m}(\mathrm{U})}$ (calculated $\mathrm{P}_{\mathrm{m} \text { (app) }}$ in Table 5). Substituting $\mathrm{P}_{\text {app }}$ and $\mathrm{P}_{\mathrm{m}}$ (app) in Equation (2), the apparent UWL permeability ( $\mathrm{P}_{\mathrm{UWL}}$ (app) ) was calculated (calculated $\mathrm{P}_{\mathrm{UWL}}$ (app) in Table 5). The apparent aqueous diffusivity ( $\mathrm{D}_{\mathrm{aq}(\mathrm{app})}$ ) was calculated by Equation (5) using $\mathrm{P}_{\mathrm{UWL} \text { (app) }}$ and $\mathrm{h}_{\mathrm{UWL}(\mathrm{app})}=100 \mu \mathrm{m}$ (calculated $\mathrm{D}_{\mathrm{aq}(\mathrm{app})}$ in Table 5). Substituting $\mathrm{F}_{\mathrm{U}}$, $\mathrm{D}_{\mathrm{aq}}(\mathrm{app})$, and $\mathrm{D}_{\mathrm{aq}}(\mathrm{U})$ in Equation (9), the aqueous diffusivity of drug molecules bound to SLS ( $\mathrm{D}_{\mathrm{aq}(\mathrm{B})}$ ) was calculated (calculated $\mathrm{D}_{\mathrm{aq} \text { (B) }}$ in Table 5). As for triamcinolone, $\mathrm{D}_{\mathrm{aq} \text { (B) }}$ was not calculated in this study. The reason for this is the fraction of the drug molecules bound to SLS in the donor chamber would be too small to calculate the impact of SLSbound molecules on the apparent permeability using the method described above. As for griseofulvin, assuming that Equation (13) applies to SLS-bound drug molecules, their sizes were estimated to be around MW 20,000 Da. As the aggregated number of SLS in aqueous solutions was reported to be 62 , their micellar weight appeared to be around $18,000 \mathrm{Da}$ [52]. Therefore, the calculated $\mathrm{D}_{\mathrm{aq}}$ (B) agreed roughly with the reported micellar size formed by SLS. Assuming this micellar size is constant, permeability and flux could be calculated by Equation (10) and Equation (12) using the apparent solubility. The apparent solubility increased in proportion to the amount of SLS. When the sample concentration in the donor chamber remained at $5 \mu \mathrm{g} / \mathrm{mL}$ under sink conditions, flux and apparent permeability decreased as apparent solubility increased, as shown in Figure 6. For example, if the apparent solubility increased by 5 and 10 times, the apparent permeability and flux reduced to about $1 / 4$ and $1 / 7$, respectively. 
Table 5. Measured and calculated permeability in $\mathrm{pH} 6.5$ buffer $+0.05 \%$ SLS.

\begin{tabular}{ccc}
\hline Compound & Griseofulvin & Triamcinolone \\
\hline Measured $\mathrm{P}_{\text {app }}(\mathrm{cm} / \mathrm{min})^{1}$ & $0.00648 \pm 0.00026$ & $0.000263 \pm 0.000028$ \\
\hline Calculated $\mathrm{P}_{\mathrm{m} \text { (app) }}(\mathrm{cm} / \mathrm{min})$ & 0.0112 & 0.000300 \\
Calculated $\mathrm{P}_{\mathrm{UWL}}(\mathrm{app})(\mathrm{cm} / \mathrm{min})$ & 0.0153 & 0.0212 \\
Calculated $\mathrm{P}_{\text {app }}(\mathrm{cm} / \mathrm{min})$ & 0.00648 & 0.000263 \\
\hline Calculated $\mathrm{D}_{\text {aq }}(\mathrm{app})\left(\mathrm{cm}^{2} / \mathrm{s}\right)$ & $2.56 \times 10^{-6}$ & $3.54 \times 10^{-7}$ \\
Calculated $\mathrm{D}_{\text {aq }}(\mathrm{B})\left(\mathrm{cm}^{2} / \mathrm{s}\right)$ & $8.37 \times 10^{-7}$ & - \\
\hline
\end{tabular}

${ }^{1}$ Results represent the average $\mathrm{P}_{\mathrm{app}} \pm \mathrm{SD}(n=3)$.

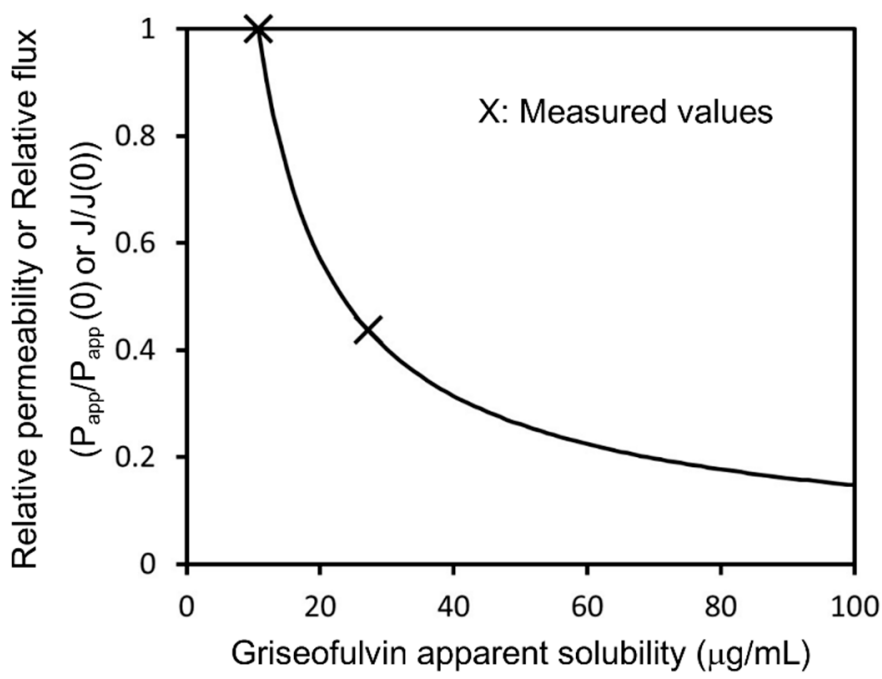

Figure 6. Calculated relationship between flux/apparent permeability and apparent solubility under sink conditions for griseofulvin. It was assumed that the sample concentration in the donor chamber remained at $5 \mu \mathrm{g} / \mathrm{mL}$ during the measurements. $P_{\text {app }}(0)$ is the apparent permeability in the absence of solubilizer additives. $\mathrm{J}(0)$ is the flux in the absence of solubilizer additives.

\section{Discussion}

The results of this study suggest that the impact of SLS on permeability and flux under sink conditions is different from that under non-sink conditions. Additionally, we confirmed that permeability and flux could increase depending on the sample dose amount in the donor chamber. In this section, we discuss the solubility-permeability relationship and the absorption mechanism under non-sink conditions.

Under non-sink conditions, the apparent solubility of griseofulvin increased by the addition of SLS, and flux was calculated using Equations (10) and (12) (Figure 7). The equations express the increase in the drug amount diffusing in the UWL, which was due to the SLS-bound drug molecules. The enhancement of flux by the addition of SLS was consistent with the measured values at each sample dose.

In addition to UFDs and SLS-bound drugs, solid drugs in the donor chamber are also under non-sink conditions. Some studies indicate that solid drugs can exist in the UWL on the membrane [37,53-56]. A nearly saturated high-concentration layer is known to form on the surface of solid drugs [57] (pp. 263-264). If solid drugs are in the UWL under non-sink conditions, then the drug diffusion mechanism in the UWL may be different under sink and non-sink conditions (Figure 8). Under sink conditions, drug molecules in the UWL would be diffused from the UWL interface to the membrane. Under non-sink conditions, in addition to diffusion in the UWL, the drug molecules could also be diffused from the high-concentration layer on the solid drugs in the UWL to the membrane. This solid drug diffusion could decrease the apparent UWL thickness, as described in Figure 8. Because the drug molecules could be diffused from the surface of solid drug, the apparent UWL thickness reduction could depend on the total surface area of solid drugs in the UWL. 
If the amount of solid drug increases or the particle size decreases, the apparent UWL thickness could also decrease, increasing permeability and flux as a result. Some studies have proposed a similar absorption mechanism, demonstrating this solid drug effect on in vivo and in vitro absorption [37-39].

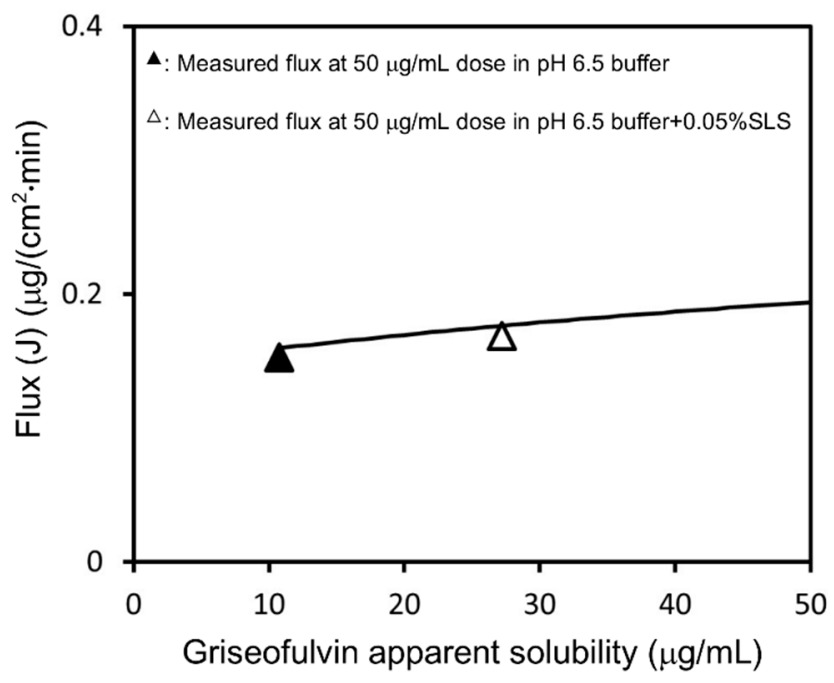

Figure 7. Calculated flux-apparent solubility relationship under sink conditions for griseofulvin. It is assumed that the UWL thickness remained constant. The results of flux measurement at a $50 \mu \mathrm{g} / \mathrm{mL}$ sample dose in $\mathrm{pH} 6.5$ buffer and $\mathrm{pH} 6.5$ buffer $+0.05 \%$ SLS were plotted.

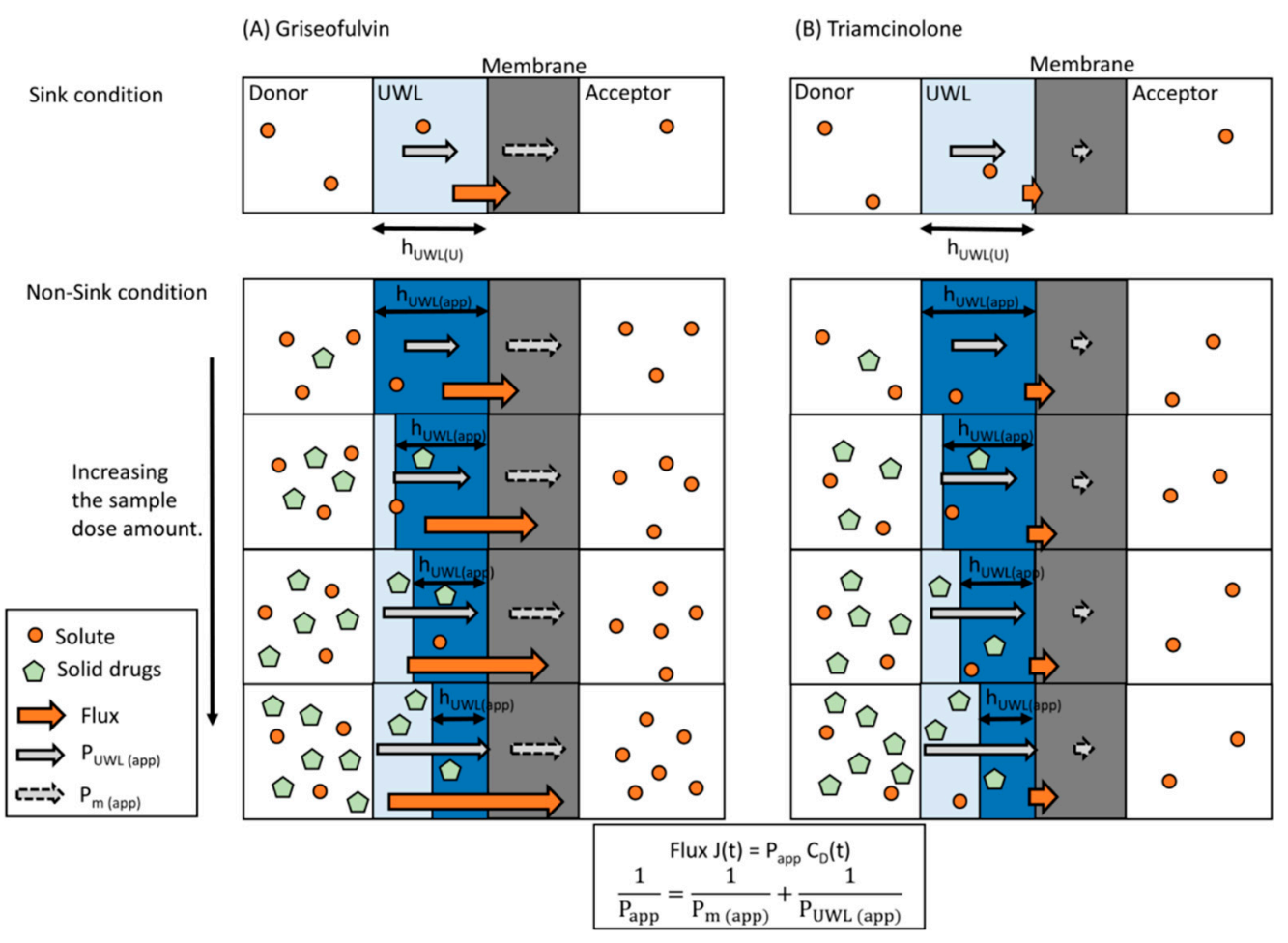

Figure 8. Proposed drug absorption mechanism under sink conditions and non-sink conditions for griseofulvin (A) and triamcinolone (B). Longer arrows represent higher flux, $\mathrm{P}_{\mathrm{UWL}}(\mathrm{app})$, or $\mathrm{P}_{\mathrm{m}}$ (app)

Based on this absorption mechanism, the apparent UWL thickness in this study decreased as the sample dose increased in the donor chamber. As shown in Figures 2 and 3, griseofulvin permeability and flux in both $\mathrm{pH} 6.5$ buffer and $\mathrm{pH} 6.5$ buffer $+0.05 \%$ SLS increased with the sample dose under non-sink conditions. When $\mathrm{pH} 6.5$ buffer is in the 
donor chamber, the apparent UWL thickness is expressed using Equations (2) and (6) as shown in Equation (14):

$$
\mathrm{h}_{\mathrm{UWL}(\mathrm{app})}=\mathrm{D}_{\mathrm{aq}(\mathrm{U})}\left(\frac{1}{\mathrm{P}_{\mathrm{app}}}-\frac{1}{\mathrm{P}_{\mathrm{m}(\mathrm{U})}}\right)
$$

When $\mathrm{pH} 6.5$ buffer $+0.05 \%$ SLS is in the donor chamber, the apparent UWL thickness is expressed using Equations (2) and (5) as shown in Equation (15):

$$
\mathrm{h}_{\mathrm{UWL}(\mathrm{app})}=\mathrm{D}_{\mathrm{aq}(\mathrm{app})}\left(\frac{1}{\mathrm{P}_{\mathrm{app}}}-\frac{1}{\mathrm{P}_{\mathrm{m}(\mathrm{app})}}\right)
$$

As for griseofulvin, substituting measured $\mathrm{P}_{\mathrm{app}}, \mathrm{P}_{\mathrm{m}(\mathrm{U})}, \mathrm{P}_{\mathrm{m}(\mathrm{app})}, \mathrm{D}_{\mathrm{aq}(\mathrm{U})}$, and $\mathrm{D}_{\mathrm{aq}(\mathrm{U})}$ in Equations (14) and (15), the apparent UWL thickness for each test condition was calculated, as shown in Figure 9. When the sample dose increased from $50 \mu \mathrm{g} / \mathrm{mL}$ to $1000 \mu \mathrm{g} / \mathrm{mL}$, the apparent UWL thickness reduced from $100 \mu \mathrm{m}$ to around $60-70 \mu \mathrm{m}$. When the apparent solubility increased by SLS, the effect of UWL thinning on the $\mathrm{P}_{\mathrm{app}}$ of griseofulvin was calculated using Equations (2), (3), and (9) as shown in Equation (16):

$$
\mathrm{P}_{\mathrm{app}}=\frac{1}{\mathrm{~F}_{\mathrm{U}} \mathrm{P}_{\mathrm{m}(\mathrm{U})}}-\frac{\mathrm{h}_{\mathrm{UWL}(\mathrm{app})}}{\mathrm{F}_{\mathrm{U}} \mathrm{D}_{\mathrm{aq}(\mathrm{U})}+\left(1-\mathrm{F}_{\mathrm{U}}\right) \mathrm{D}_{\mathrm{aq}}(\mathrm{B})}
$$

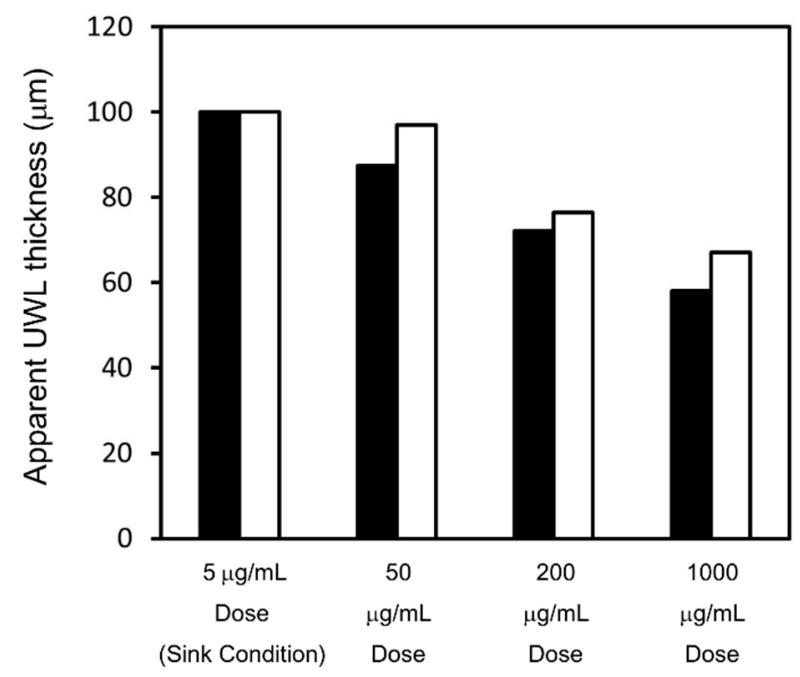

Figure 9. The calculated apparent UWL thickness ( $\mathrm{h}_{\mathrm{UWL}}(\mathrm{app})$ of griseofulvin for each flux measurement. $h_{U W L}$ (app) in pH 6.5 buffer is represented by black bars. $h_{U W L}$ (app) in pH 6.5 buffer $+0.05 \%$ SLS is represented by white bars.

If the test sample in the donor chamber was under non-sink conditions, the sample concentration would be equal to the apparent solubility. Therefore, the effect of UWL thinning on the flux of griseofulvin could be estimated using Equation (1) and Equation (16), as shown in Figure 10. This explains how SLS addition and an increase in dose enhance flux. 


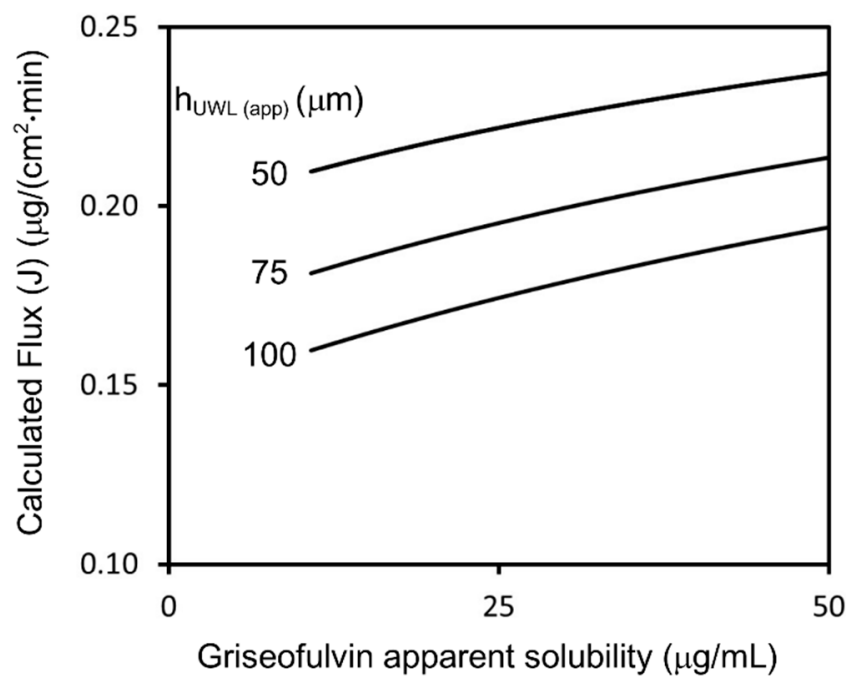

Figure 10. Calculated flux of griseofulvin for 50-100 $\mu \mathrm{m}$ apparent UWL thickness.

As the MW of oral pharmaceutical drugs is generally reported to be around 200-1000 $\mathrm{Da}$, the variability of $\mathrm{D}_{\mathrm{aq}}(\mathrm{U})$ might be very small, based on Equation (13), compared with the variability of $\mathrm{P}_{\mathrm{m}(\mathrm{U})}$. $\mathrm{P}_{\mathrm{m}(\mathrm{U})}$ is generally known to show a large variation. To simply calculate the effect of UWL thinning on the permeability and flux of various drugs, we used a neutral model compound with an MW of $400 \mathrm{Da}$ and $\mathrm{pH} 6.5$ buffer as the donor chamber test media for the following calculations. When the $\mathrm{P}_{\mathrm{m}(\mathrm{U})}$ of this model compound was $0.001-1 \mathrm{~cm} / \mathrm{min}$, the relationship between UWL thickness and flux/permeability was calculated by Equation (17), as shown in Figure 11:

$$
\mathrm{P}_{\mathrm{app}}=\frac{1}{\mathrm{P}_{\mathrm{m}(\mathrm{U})}}-\frac{\mathrm{h}_{\mathrm{UWL}(\mathrm{app})}}{\mathrm{D}_{\mathrm{aq}(\mathrm{U})}}
$$

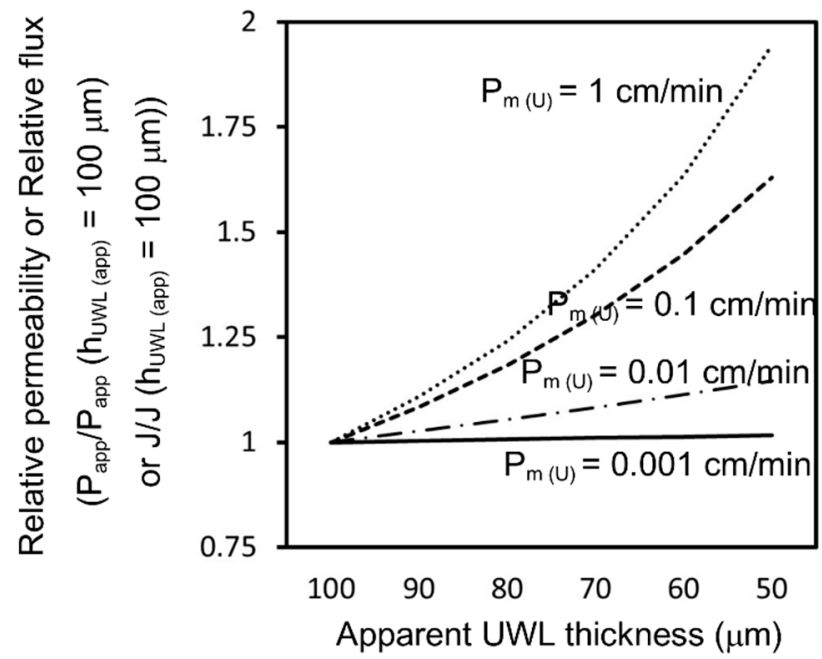

Figure 11. Calculated relationship between apparent permeability/flux and apparent UWL thickness for model compounds with $\mathrm{P}_{\mathrm{m}(\mathrm{U})}$ of $0.001-1 \mathrm{~cm} / \mathrm{min}$. It was assumed that the $\mathrm{MW}$ of the model compounds was 400 Da.

The $\mathrm{P}_{\mathrm{m}(\mathrm{U})}$ of triamcinolone was around $0.0003 \mathrm{~cm} / \mathrm{min}$. According to Figure 11, the permeability and flux for triamcinolone would be constant even if the apparent UWL thickness decreased. Therefore, the results for triamcinolone under non-sink conditions are concordant with the absorption model described above. 
In addition, Figure 11 indicates that the permeability and flux of highly permeable drugs can be strongly affected by the presence of solid drugs in the UWL. If the UWL thickness reduces by $50 \%$ for a drug with a $P_{m(U)}$ of $1 \mathrm{~cm} / \mathrm{min}$, its permeability and flux would increase by about twofold. However, it is difficult to directly predict the in vivo absorption amount using the solubility-permeability relationship estimated by MicroFlux ${ }^{\mathrm{TM}}$. Factors like movement, surface area, and solvent volume in the human GIT differ from MicroFlux ${ }^{\mathrm{TM}}$ conditions. Thus, the effect of solid drugs on UWL permeability may differ in vitro and in vivo. As for griseofulvin, Sugano suggested that solid drugs in the UWL could increase the in vivo permeability and in vivo drug absorption at a $500 \mathrm{mg}$ dose by about twofold [37]. According to this study, the in vivo effect of solid drugs on permeability and drug absorption is larger than the in vitro effect seen in the flux measurements. The in vitro $\mathrm{P}_{\mathrm{m}(\mathrm{U})}$ of griseofulvin was $0.0284 \mathrm{~cm} / \mathrm{min}$ in this study. Thus, it could be roughly predicted that the in vivo permeability and drug absorption of a drug with an in vitro $P_{m(U)}=0.005 \mathrm{~cm} / \mathrm{min}$ would increase by about $20-30 \%$ if the UWL thickness was reduced by half at the higher sample dose.

\section{Conclusions}

In this study, we examined the relationship between drug solubility, the amount of UFDs, and permeability under non-sink conditions. We found that drug molecules bound to solubilizer additives and solid drugs can enhance UWL permeability, resulting in increased flux or permeability under non-sink conditions. Conventional methods of measuring permeability, like Caco-2 or Parallel Artificial Membrane Permeability Assay (PAMPA), are performed under sink conditions. On the other hand, a lot of BCS class II and IV drugs cannot be adequately dissolved in the GIT, meaning that they are under non-sink conditions there. If we use conventional methods to predict the absorption of highly permeable drugs, the predicted amount could be much lower than the actual amount. Therefore, as the results of this study suggest, it is necessary to understand how the solubility-permeability relationship under non-sink conditions reflects the clinical context. MicroFlux ${ }^{\mathrm{TM}}$ and the test conditions used in this study may be effective tools for assessing such effects on drug absorption. Not enough is known about the correlation between in vivo permeability and permeability, as estimated by MicroFlux ${ }^{\mathrm{TM}}$. However, by combining flux measurements with physiologically based pharmacokinetics (PBPK) modeling, we will be able to accurately predict the in vivo absorption for BCS class II and IV drugs in the future.

Author Contributions: Conceptualization, K.S. and N.T.; data curation, K.S.; formal analysis, K.S.; funding acquisition, K.S.; investigation, K.S.; methodology, K.S.; project administration, K.S.; resources, K.S.; software, K.S.; supervision, N.T. and E.Y.; validation, K.S.; visualization, K.S.; writingoriginal draft, K.S.; writing-review and editing, N.T. and E.Y. All authors have read and agreed to the published version of the manuscript.

Funding: This research was funded by Chugai Pharma Manufacturing Co., Ltd.

Institutional Review Board Statement: Not applicable.

Informed Consent Statement: Not applicable.

Data Availability Statement: The data presented in this study are available in this article.

Acknowledgments: We are deeply grateful to the members of our laboratories for giving us the chance to do this exciting work. We thank our colleagues in Chugai for their support and technical advice. We thank Kazutoshi Tabata for his assistance in setting flux measurements.

Conflicts of Interest: K.S. and N.T. are researchers currently employed by Chugai Pharma Manufacturing Co., Ltd. The funders/companies had no role in the design of the study; in the collection, analyses, or interpretation of data; in the writing of the manuscript, or in the decision to publish the results. The authors declare no conflict of interest. 


\section{Appendix A}

See Figures A1 and A2.

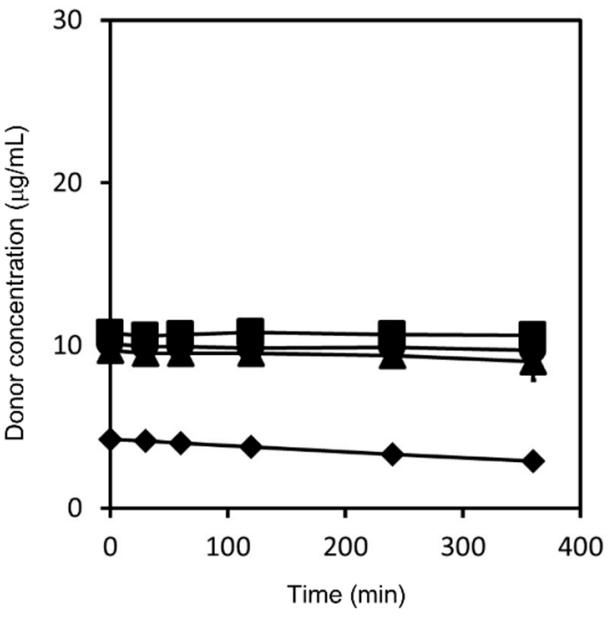

(a) $\mathrm{pH} 6.5$ buffer

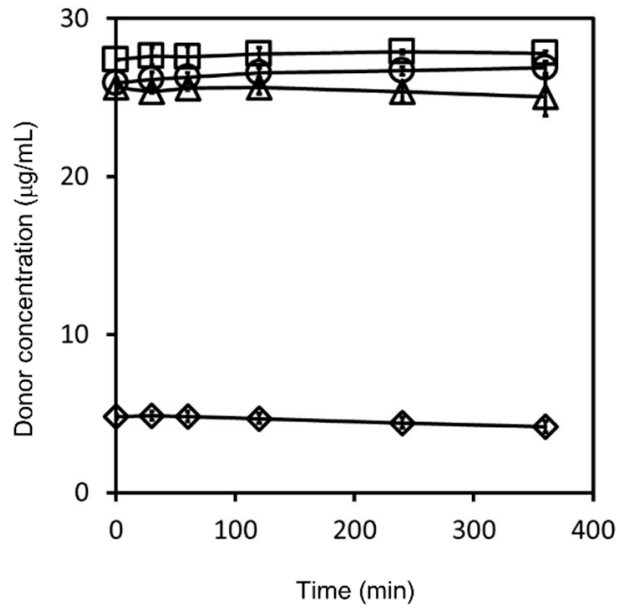

(b) $\mathrm{pH} 6.5$ buffer $+0.05 \%$ SLS

Figure A1. Griseofulvin concentration-time profile in the donor chamber, as determined by flux measurements. Measurements in $\mathrm{pH} 6.5$ buffer are represented by closed symbols for the $5 \mathrm{\mu g} / \mathrm{mL}$ sample dose $(\bullet), 50 \mu \mathrm{g} / \mathrm{mL}$ sample dose $(\mathbf{\Lambda}), 200 \mu \mathrm{g} / \mathrm{mL}$ sample dose $(\bullet)$, and $1000 \mu \mathrm{g} / \mathrm{mL}$ sample

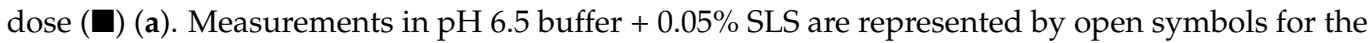
$5 \mu \mathrm{g} / \mathrm{mL}$ sample dose $(\diamond), 50 \mu \mathrm{g} / \mathrm{mL}$ sample dose $(\triangle), 200 \mu \mathrm{g} / \mathrm{mL}$ sample dose $(\bigcirc)$, and $1000 \mu \mathrm{g} / \mathrm{mL}$ sample dose $(\square)(\mathbf{b})$. Results represent the average griseofulvin concentration $\pm \mathrm{SD}(n=3)$.

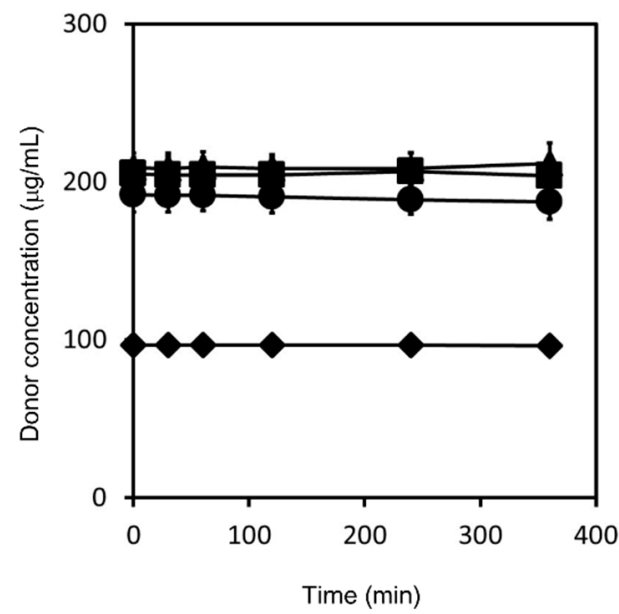

(a) $\mathrm{pH} 6.5$ buffer

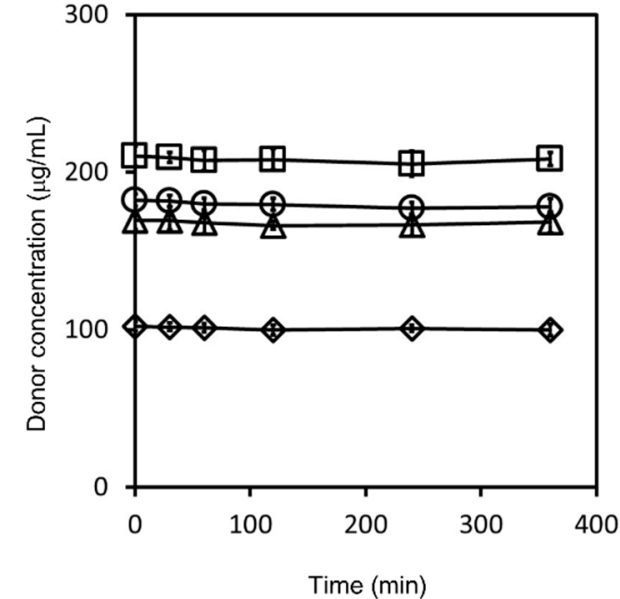

(b) $\mathrm{pH} 6.5$ buffer $+0.05 \%$ SLS

Figure A2. Triamcinolone concentration-time profile in the donor chamber, as determined by flux measurements. Measurements in $\mathrm{pH} 6.5$ buffer are represented by closed symbols for the $100 \mathrm{\mu g} / \mathrm{mL}$ sample dose ( $\bullet$ ), $500 \mu \mathrm{g} / \mathrm{mL}$ sample dose $(\mathbf{\Lambda}), 2000 \mu \mathrm{g} / \mathrm{mL}$ sample dose $(\bullet)$, and 10,000 $\mu \mathrm{g} / \mathrm{mL}$

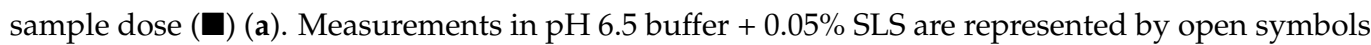
for the $100 \mu \mathrm{g} / \mathrm{mL}$ sample dose $(\diamond), 500 \mu \mathrm{g} / \mathrm{mL}$ sample dose $(\triangle), 2000 \mu \mathrm{g} / \mathrm{mL}$ sample dose $(\bigcirc)$, and $10,000 \mu \mathrm{g} / \mathrm{mL}$ sample dose $(\square)(\mathbf{b})$. Results represent the average triamcinolone concentration $\pm \mathrm{SD}$ $(n=3)$. 


\section{References}

1. Boyd, B.J.; Bergström, C.A.; Vinarov, Z.; Kuentz, M.; Brouwers, J.; Augustijns, P.; Brandl, M.; Bernkop-Schnürch, A.; Shrestha, N.; Préat, V.; et al. Successful oral delivery of poorly water-soluble drugs both depends on the intraluminal behavior of drugs and of appropriate advanced drug delivery systems. Eur. J. Pharm. Sci. 2019, 137, 104967. [CrossRef] [PubMed]

2. Butler, J.M.; Dressman, J.B. The Developability Classification System: Application of Biopharmaceutics Concepts to Formulation Development. J. Pharm. Sci. 2010, 99, 4940-4954. [CrossRef]

3. Rosenberger, J.; Butler, J.; Dressman, J. A Refined Developability Classification System. J. Pharm. Sci. 2018, 107, 2020-2032. [CrossRef]

4. Rosenberger, J.; Butler, J.; Muenster, U.; Dressman, J. Application of a Refined Developability Classification System. J. Pharm. Sci. 2019, 108, 1090-1100. [CrossRef]

5. Lennernäs, H.; Aarons, L.; Augustijns, P.; Beato, S.; Bolger, M.; Box, K.; Brewster, M.; Butler, J.; Dressman, J.; Holm, R.; et al. Oral biopharmaceutics tools-Time for a new initiative-An introduction to the IMI project OrBiTo. Eur. J. Pharm. Sci. 2014, 57, 292-299. [CrossRef]

6. Kostewicz, E.S.; Abrahamsson, B.; Brewster, M.; Brouwers, J.; Butler, J.; Carlert, S.; Dickinson, P.A.; Dressman, J.; Holm, R.; Klein, S.; et al. In vitro models for the prediction of in vivo performance of oral dosage forms. Eur. J. Pharm. Sci. 2014, 57, 342-366. [CrossRef]

7. $\quad$ Lennernäs, H.; Lindahl, A.; Van Peer, A.; Ollier, C.; Flanagan, T.; Lionberger, R.; Nordmark, A.; Yamashita, S.; Yu, L.; Amidon, G.L.; et al. In Vivo Predictive Dissolution (IPD) and Biopharmaceutical Modeling and Simulation: Future Use of Modern Approaches and Methodologies in a Regulatory Context. Mol. Pharm. 2017, 14, 1307-1314. [CrossRef]

8. Tsume, Y.; Mudie, D.M.; Langguth, P.; Amidon, G.E.; Amidon, G.L. The Biopharmaceutics Classification System: Subclasses for in vivo predictive dissolution (IPD) methodology and IVIVC. Eur. J. Pharm. Sci. 2014, 57, 152-163. [CrossRef]

9. Food and Drug Administration. Guidance for Industry. Immediate Release Solid Oral Dosage Forms, Scale-Up and Post-Approval Changes: Chemistry, Manufacturing, and Controls, In Vitro Dissolution Testing, and In Vivo Bioequivalence Documentation; FDA: Rockville, MD, USA, 1995.

10. Ministry of Health, Labour and Welfare (MHLW). Guideline for Bioequivalence Studies of Generic Products (Revision); MHLW: Tokyo, Japan, 2012.

11. MHLW. Guideline for Bioequivalence Studies of Generic Products for Different Strengths of Oral Solid Dosage Forms (Revision); MHLW: Tokyo, Japan, 2012.

12. European Medicines Agency. Guideline on the Investigation of Bioequivalence; EMA: London, UK, 2010.

13. Kuribayashi, R.; Takishita, T.; Mikami, K. Regulatory Considerations of Bioequivalence Studies for Oral Solid Dosage Forms in Japan. J. Pharm. Sci. 2016, 105, 2270-2277. [CrossRef]

14. European Medicines Agency. ICH Q6A Specifications: Test Procedures and Acceptance Criteria for New Drug Substances and New Drug Products: Chemical Substances; European Medicines Agency: London, UK, 2000.

15. Amidon, G.L.; Lennernäs, H.; Shah, V.P.; Crison, J.R. A theoretical basis for a biopharmaceutic drug classification: The correlation of in vitro drug product dissolution and in vivo bioavailability. Pharm. Res. 1995, 12, 413-420. [CrossRef]

16. Van Der Merwe, J.; Steenekamp, J.; Steyn, D.; Hamman, J. The Role of Functional Excipients in Solid Oral Dosage Forms to Overcome Poor Drug Dissolution and Bioavailability. Pharmaceutics 2020, 12, 393. [CrossRef]

17. Williams, H.D.; Trevaskis, N.L.; Charman, S.A.; Shanker, R.M.; Charman, W.N.; Pouton, C.W.; Porter, C.J.H. Strategies to Address Low Drug Solubility in Discovery and Development. Pharmacol. Rev. 2013, 65, 315-499. [CrossRef]

18. Sun, D.D.; Wen, H.; Taylor, L.S. Non-Sink Dissolution Conditions for Predicting Product Quality and In Vivo Performance of Supersaturating Drug Delivery Systems. J. Pharm. Sci. 2016, 105, 2477-2488. [CrossRef]

19. Sun, D.D.; Lee, P.I. Haste Makes Waste: The Interplay Between Dissolution and Precipitation of Supersaturating Formulations. AAPS J. 2015, 17, 1317-1326. [CrossRef]

20. Phillips, D.J.; Pygall, S.R.; Cooper, V.B.; Mann, J.C. Overcoming sink limitations in dissolution testing: A review of traditional methods and the potential utility of biphasic systems. J. Pharm. Pharmacol. 2012, 64, 1549-1559. [CrossRef]

21. Miyaji, Y.; Fujii, Y.; Takeyama, S.; Kawai, Y.; Kataoka, M.; Takahashi, M.; Yamashita, S. Advantage of the Dissolution/Permeation System for Estimating Oral Absorption of Drug Candidates in the Drug Discovery Stage. Mol. Pharm. 2016, 13, 1564-1574. [CrossRef]

22. Sun, D.; Hu, M.; Browning, M.; Friedman, R.L.; Jiang, W.; Zhao, L.; Wen, H. Dissolution Failure of Solid Oral Drug Products in Field Alert Reports. J. Pharm. Sci. 2017, 106, 1302-1309. [CrossRef]

23. Dahan, A.; Miller, J.M. The Solubility-Permeability Interplay and Its Implications in Formulation Design and Development for Poorly Soluble Drugs. AAPS J. 2012, 14, 244-251. [CrossRef]

24. Dahan, A.; Beig, A.; Lindley, D.; Miller, J.M. The solubility-permeability interplay and oral drug formulation design: Two heads are better than one. Adv. Drug Deliv. Rev. 2016, 101, 99-107. [CrossRef] [PubMed]

25. Porat, D.; Dahan, A. Active intestinal drug absorption and the solubility-permeability interplay. Int. J. Pharm. 2018, 537, 84-93. [CrossRef]

26. Nainwal, N.; Singh, R.; Jawla, S.; Saharan, V.A. The Solubility-Permeability Interplay for Solubility-Enabling Oral Formulations. Curr. Drug Targets 2019, 20, 1434-1446. [CrossRef] 
27. Dahlgren, D.; Lennernäs, H. Intestinal Permeability and Drug Absorption: Predictive Experimental, Computational and In Vivo Approaches. Pharmaceutics 2019, 11, 411. [CrossRef] [PubMed]

28. Zhu, L.; Lu, L.; Wang, S.; Wu, J.; Shi, J.; Yan, T.; Xie, C.; Li, Q.; Hu, M.; Liu, Z. Chapter 11. Oral Absorption Basics: Pathways and Physicochemical and Biological Factors Affecting Absorption. In Developing Solid Oral Dosage Forms, 2nd ed.; Qiu, Y., Ed.; Academic Press: Cambridge, MA, USA, 2017; pp. 297-329.

29. Raina, S.A.; Zhang, G.G.Z.; Alonzo, D.E.; Wu, J.; Zhu, D.; Catron, N.D.; Gao, Y.; Taylor, L.S. Impact of Solubilizing Additives on Supersaturation and Membrane Transport of Drugs. Pharm. Res. 2015, 32, 3350-3364. [CrossRef] [PubMed]

30. Shore, P.A.; Brodie, B.B.; Hogben, C.A. The gastric secretion of drugs: A phpartition hypothesis. J. Pharmacol. Exp. Ther. 1957, 119, 361-369. [PubMed]

31. Beig, A.; Agbaria, R.; Dahan, A. Oral Delivery of Lipophilic Drugs: The Tradeoff between Solubility Increase and Permeability Decrease When Using Cyclodextrin-Based Formulations. PLoS ONE 2013, 8, e68237. [CrossRef]

32. Beig, A.; Miller, J.M.; Dahan, A. The interaction of nifedipine with selected cyclodextrins and the subsequent solubilitypermeability trade-off. Eur. J. Pharm. Biopharm. 2013, 85, 1293-1299. [CrossRef] [PubMed]

33. Beig, A.; Agbaria, R.; Dahan, A. The use of captisol (SBE7- $\beta-C D)$ in oral solubility-enabling formulations: Comparison to HP $\beta C D$ and the solubility-permeability interplay. Eur. J. Pharm. Sci. 2015, 77, 73-78. [CrossRef] [PubMed]

34. Miller, J.M.; Beig, A.; Krieg, B.J.; Carr, R.A.; Borchardt, T.B.; Amidon, G.E.; Amidon, G.L.; Dahan, A. The Solubility-Permeability Interplay: Mechanistic Modeling and Predictive Application of the Impact of Micellar Solubilization on Intestinal Permeation. Mol. Pharm. 2011, 8, 1848-1856. [CrossRef]

35. Hens, B.; Brouwers, J.; Corsetti, M.; Augustijns, P. Gastrointestinal behavior of nano- and microsized fenofibrate: In vivo evaluation in man and in vitro simulation by assessment of the permeation potential. Eur. J. Pharm. Sci. 2015, 77, 40-47. [CrossRef] [PubMed]

36. Amidon, G.E.; Higuchi, W.I.; Ho, N.F.H. Theoretical and Experimental Studies of Transport of Micelle-Solubilized Solutes. J. Pharm. Sci. 1982, 71, 77-84. [CrossRef]

37. Sugano, K. Possible reduction of effective thickness of intestinal unstirred water layer by particle drifting effect. Int. J. Pharm. 2010, 387, 103-109. [CrossRef]

38. Imono, M.; Uchiyama, H.; Yoshida, S.; Miyazaki, S.; Tamura, N.; Tsutsumimoto, H.; Kadota, K.; Tozuka, Y. The elucidation of key factors for oral absorption enhancement of nanocrystal formulations: In vitro-in vivo correlation of nanocrystals. Eur. J. Pharm. Biopharm. 2020, 146, 84-92. [CrossRef]

39. Arce, F.A.; Setiawan, N.; Campbell, H.R.; Lu, X.; Nethercott, M.J.; Bummer, P.; Su, Y.; Marsac, P.J. Toward Developing Discriminating Dissolution Methods for Formulations Containing Nanoparticulates in Solution: The Impact of Particle Drift and Drug Activity in Solution. Mol. Pharm. 2020, 17, 4125-4140. [CrossRef] [PubMed]

40. Guo, J.; Elzinga, P.A.; Hageman, M.; Herron, J.N. Rapid Throughput Solubility Screening Method for BCS Class II Drugs in Animal GI Fluids and Simulated Human GI Fluids Using a 96-well Format. J. Pharm. Sci. 2008, 97, 1427-1442. [CrossRef] [PubMed]

41. Mithani, S.D.; Bakatselou, V.; TenHoor, C.N.; Dressman, J.B. Estimation of the Increase in Solubility of Drugs as a Function of Bile Salt Concentration. Pharm. Res. 1996, 13, 163-167. [CrossRef]

42. Bakatselou, V.; Oppenheim, R.C.; Dressman, J.B. Solubilization and Wetting Effects of Bile Salts on the Dissolution of Steroids. Pharm. Res. 1991, 8, 1461-1469. [CrossRef]

43. Tsinman, K.; Tsinman, O.; Lingamaneni, R.; Zhu, S.; Riebesehl, B.; Grandeury, A.; Juhnke, M.; Van Eerdenbrugh, B. Ranking Itraconazole Formulations Based on the Flux through Artificial Lipophilic Membrane. Pharm. Res. 2018, 35, 161. [CrossRef]

44. Avdeef, A. Leakiness and Size Exclusion of Paracellular Channels in Cultured Epithelial Cell Monolayers-Interlaboratory Comparison. Pharm. Res. 2010, 27, 480-489. [CrossRef] [PubMed]

45. Dahan, A.; Miller, J.M.; Hoffman, A.; Amidon, G.E.; Amidon, G.L. The Solubility-Permeability Interplay in Using Cyclodextrins as Pharmaceutical Solubilizers: Mechanistic Modeling and Application to Progesterone. J. Pharm. Sci. 2010, 99, $2739-2749$. [CrossRef]

46. Sugano, K. Aqueous Boundary Layers Related to Oral Absorption of a Drug: From Dissolution of a Drug to Carrier Mediated Transport and Intestinal Wall Metabolism. Mol. Pharm. 2010, 7, 1362-1373. [CrossRef] [PubMed]

47. Korjamo, T.; Heikkinen, A.T.; Waltari, P.; Mönkkönen, J. The Asymmetry of the Unstirred Water Layer in Permeability Experiments. Pharm. Res. 2008, 25, 1714-1722. [CrossRef] [PubMed]

48. Safety Data in IPEC Japan. Available online: http://www.jpec.gr.jp/detail=normal\&date=safetydata $/ \mathrm{ra} / \mathrm{dara3}$.html (accessed on 30 November 2020).

49. Schiller, C.; Frohlich, C.-P.; Giessmann, T.; Siegmund, W.; Monnikes, H.; Hosten, N.; Weitschies, W. Intestinal fluid volumes and transit of dosage forms as assessed by magnetic resonance imaging. Aliment. Pharmacol. Ther. 2005, 22, 971-979. [CrossRef]

50. Mudie, D.M.; Murray, K.; Hoad, C.L.; Pritchard, S.E.; Garnett, M.C.; Amidon, G.L.; Gowland, P.A.; Spiller, R.C.; Amidon, G.E.; Marciani, L. Quantification of Gastrointestinal Liquid Volumes and Distribution Following a $240 \mathrm{~mL}$ Dose of Water in the Fasted State. Mol. Pharm. 2014, 11, 3039-3047. [CrossRef] [PubMed]

51. Avdeef, A. Chapter 7. Permeability-PAMPA. In Absorption and Drug Development: Solubility, Permeability, and Charge State, 2nd ed.; John Wiley \& Sons, Inc.: Hoboken, NJ, USA, 2012; pp. 319-498. 
52. Turro, N.J.; Yekta, A. Luminescent probes for detergent solutions. A simple procedure for determination of the mean aggregation number of micelles. J. Am. Chem. Soc. 1978, 100, 5951-5952. [CrossRef]

53. Doyle-McCullough, M.; Smyth, S.; Moyes, S.; Carr, K. Factors influencing intestinal microparticle uptake in vivo. Int. J. Pharm. 2007, 335, 79-89. [CrossRef]

54. Limpanussorn, J.; Simon, L.; Dayan, A.D. Transepithelial Transport of Large Particles in Rat: A New Model for the Quantitative Study of Particle Uptake. J. Pharm. Pharmacol. 1998, 50, 753-760. [CrossRef]

55. Norris, D.A.; Puri, N.; Sinko, P.J. The effect of physical barriers and properties on the oral absorption of particulates. Adv. Drug Deliv. Rev. 1998, 34, 135-154. [CrossRef]

56. Smyth, S.; Feldhaus, S.; Schumacher, U.; Carr, K. Uptake of inert microparticles in normal and immune deficient mice. Int. J. Pharm. 2008, 346, 109-118. [CrossRef] [PubMed]

57. Chen, Y.; Wang, J.; Flanagan, D.R. Chapter 9. Fundamentals of Diffusion and Dissolution. In Developing Solid Oral Dosage Forms, 2nd ed.; Qiu, Y., Ed.; Academic Press: Cambridge, MA, USA, 2017; pp. 253-270. 